\title{
Toronto-area Ethnic Newspapers and Canada's 2011 Federal Election: An Investigation of Content, Focus and Partisanship
}

\author{
APRIL LINDGREN Ryerson University
}

\section{Introduction}

Canada's 2011 federal election was notable for, among other things, determined efforts by politicians to woo voters from so-called "ethnic" communities, a catchall phrase that encompasses citizens from immigrant, cultural, linguistic, religious and racialized groups. The governing Conservative Party of Canada (CPC) in particular upped the ante with an outreach strategy orchestrated by then-Immigration Minister Jason Kenney that included courting ethnocultural news media. Before the election call and then during the campaign itself, Prime Minister Stephen Harper and Kenney, dubbed the minister for "curry in a hurry" by party insiders (Cheadle and Levitz, 2012a), circumvented the Ottawa press gallery by offering exclusive interviews and special briefings to journalists from news outlets serving ethnocultural groups (Meyer, 2010; Taber, 2011). The prime minister decreed

April Lindgren, School of Journalism, Ryerson University, 350 Victoria Street, Toronto, Ontario M5B 2K3, Email: April.lindgren@ryerson.ca

Online Appendices are available at http://dx.doi.org/10.1017/S0008423914000912. This research was made possible by generous financial support from Ryerson University, the Ontario Metropolis Centre (CERIS) and the Social Sciences and Humanities Research Council (SSHRC). I would also like to thank research assistant Christina Wong for her work on data analysis as well as coders Emily Jin, Harbi Natt, Sue Chun and Maria Siassina for their care, diligence and enthusiasm. My thanks also to Myer Siemiatycki, who very generously made his data on visible minority candidates in the GTA available to us for analysis purposes and to Catherine Murray for her advice and encouragement.

Canadian Journal of Political Science/Revue canadienne de science politique Page 1 of 30 doi:10.1017/S0008423914000912

(C) 2014 Canadian Political Science Association (l'Association canadienne de science politique)

and/et la Société québécoise de science politique 
ethnic news media "the new mainstream media" (Cheadle and Levitz, 2012b) while a Conservative party fundraising document pinpointed 10 "very ethnic" ridings across the country and outlined plans to "positively brand [the] CPC in target communities" with a media advertising strategy aimed at the South Asian, Mandarin and Cantonese communities in particular ("Breaking Through," 2011).

The decision by Canada's political class to embrace ethnocultural media highlights the need to understand the role of these news organizations in the political process. Limited research in this area has led scholars to suggest it would be worthwhile "to investigate ethnic media's 'behaviour' during election times to better understand the type of issues that get covered, as well as how politicians and policies are addressed in the ethnic media" (Ahadi and Murray, 2009: 605). More generally, Kymlicka (2008) has identified the need for a better understanding of institutional structures, including ethnocultural media, in ethnic and immigrant communities.

This study attempts to address some of the gaps in the literature by examining news coverage of Canada's 2011 federal election in five ethnocultural newspapers published in the Greater Toronto Area (GTA). The amount of election news the papers provided is investigated along with factors that influenced the amount of coverage. The extent to which ethnic news organizations offered a narrative that is distinct from that of mainstream media is explored and evaluated in terms of Habermas' notion of the public sphere (1989) as well as Fleras' vision of ethnocultural news media as institutions that "concurrently promote cultural preservation and societal incorporation" (2011: 247). Finally, the CPC ran an aggressive ethnic media strategy during the 2011 race and emerged from the election with a majority government that included members of Parliament from all five of the "very ethnic" ridings it targeted in the GTA. In light of that, this study examined how the ethnocultural press covered the Tory campaign.

\section{Literature Review}

Why woo the ethnic media?. Over the past decade both the left-leaning New Democratic Party (NDP) and, more recently, the right-of-centre Conservatives have chipped away at immigrant and visible minority voters' traditional support for the centrist Liberal Party of Canada (Gidengil et al., 2012; Harell, 2013). While there is a long history of parties courting so-called "ethnic" voters (Champion, 2010), the issue frequently made headlines in the 2011 federal election because of the CPC's high-profile efforts to attract these voters in targeted urban ridings.

Demographics partly explain these efforts: a growing number of ridings in and around major Canadian cities are home to concentrations 


\begin{abstract}
Canada's political class is embracing ethnocultural news media with increasing zeal, highlighting the need to understand the role of these news organizations in the political process. This study investigated coverage of Canada's 2011 federal election in five Toronto-area ethnocultural newspapers. The publications, which carried campaign news to varying degrees, provided coverage that was distinct in many ways from mainstream media. Content such as the focus on ingroup candidates had the potential to strengthen community bonds while more general election news equipped readers with information that would facilitate participation in society through informed voting. Analysis of reporting about the Conservative Party of Canada, which pursued an aggressive ethnic media strategy, identified no clear pattern of stories with explicitly biased content. In most newspapers, however, the CPC did enjoy an advantage in that it received more coverage than the competition.
\end{abstract}

Résumé. La classe politique du Canada tient compte avec de plus en plus de zèle des médias ethnoculturels, soulignant la nécessité de comprendre le rôle que jouent ces organismes de presse dans le processus politique. Cette étude examine la couverture de l'élection fédérale du Canada de 2011 en examinant cinq journaux ethnoculturels de la région de Toronto. Ces journaux, qui publiaient des nouvelles de la campagne à des degrés divers, ont présenté une couverture qui se distinguait en plusieurs points des grands médias nationaux. Le contenu qui mettait l'accent sur les candidats du groupe d'appartenance avait le potentiel de renforcer les liens avec leur communauté ethnoculturelle alors que les nouvelles traitant de l'élection de manière plus générale avaient le potentiel d'outiller les lecteurs en fournissant de l'information qui faciliterait leur participation à la société canadienne, leur permettant ainsi de faire un vote plus éclairé. L'analyse des contenus médiatiques sur le Parti conservateur du Canada, qui a mis en œuvre une stratégie agressive à l'égard des médias ethniques, n'a pas permis de dégager de tendance nette où les nouvelles seraient explicitement biaisées à la faveur de ces groupes. Cependant, dans la plupart de ces journaux, le PCC a profité d'une couverture plus large que ses adversaires.

of potential supporters from single ethnocultural groups. The CPC's interest in electoral districts where one ethnic group accounted for more than 20 per cent of the population made headlines after reporters obtained a party document that identified 10 ridings the Conservatives deemed "very ethnic" and potentially winnable ("Breaking Through," 2011). The list of ridings, which subsequent reports suggested expanded to include as many as 30 electoral districts (Payton, 2012), included five in the GTA: Eglinton-Lawrence and York Centre, two ridings with significant concentrations of Jewish voters; Richmond Hill, where 23.5 per cent of the population is of Chinese background; and the City of Brampton ridings of Brampton-Springdale and neighbouring Bramalea-Gore-Malton, where South Asians account for 32.1 per cent and 39.6 per cent of the population respectively (Statistics Canada, 2008). In Brampton overall, 17.5 per cent of residents list Punjabi as their mother tongue, making it the city's leading non-official language (City of Brampton, 2012).

Demographic reality in 2011 meshed nicely with the CPC's growing conviction that a platform of fiscal conservatism and tough-on-crime rhetoric would attract ethnic and immigrant voters (Bricker and Ibbitson, 2013; Hyder, 2005). The party also armed itself with increasingly sophisticated tools for identifying and tracking potential supporters, tools that helped 
the Conservatives draft policies catering to specific groups and even court individual Jewish, Chinese and other voters by sending them best wishes on their respective community holidays (Delacourt, 2013).

A media strategy crafted to reach ethnocultural communities was another major ingredient in what would turn out to be a successful Conservative campaign. Many voters lack the time and opportunity to participate directly in political events and therefore count on journalists to be their eyes and ears (Soroka et al., 2009). Indeed, it is "free media coverage that candidates rely on to energize, turn out, and provide information to the undecided voter" (Herr, 2002: 906).

Residents in the GTA in search of such information can turn to an array of news media produced by and for immigrants and linguistic, cultural and racialized groups. The GTA, which includes the City of Toronto and two dozen other municipalities in the immediate environs, is served by myriad radio, television and online news outlets operating in dozens of languages. Suburban Brampton, just northwest of Toronto, for instance, has an estimated 75 newspapers and more than 55 radio and television productions (Bascaramurty, 2013) serving its 91,000 Punjabi-speaking residents (City of Brampton, 2012). Region-wide, as many as ten daily newspapers catering to different ethnocultural communities are available at any given time (Diversity Institute, 2010) along with more than 200 other free publications that appear less frequently (DiversiPro, 2007).

While the circulation of individual ethnocultural newspapers is small compared to the GTA's mainstream English-language press, politicians are nonetheless eager to appear in these publications because they have committed audiences that can't necessarily be reached through mainstream media. Canada's fast-growing Chinese and South Asian communities are particularly dedicated consumers of ethnocultural media: 75 per cent of Chinese and South Asian residents surveyed in Toronto, Montreal and Vancouver said they turned to at least one ethnic newspaper, radio or television station for news in the previous week (Solutions Research Group, 2006). Other research on Chinese immigrants in the Toronto and Vancouver areas found that 52 per cent of respondents read Chinese-language newspapers and magazines exclusively (Fairchild Television, 2007).

Theoretical frameworks. Readers turn to ethnocultural newspapers for a variety of reasons. The newspapers offer narratives that counter negative stereotypes in mainstream media (Husband, 2005). They help preserve language and culture in a way that builds a sense of community (Zhou and Cai, 2002), provide practical information for everyday living and help newcomers understand their adopted society while keeping them abreast of events in their country of origin (Lindgren, 2011). Ethnocultural news outlets also serve readers and viewers who struggle with English or, in many cases, simply feel more comfortable consuming news reported in their mother 
tongue. Consequently, "when politicians attempt to reach these electorates in their own cultural idioms, ethnic media become key vehicles" (Karim, 2002: 239).

Research on the role of ethnic media during elections, however, remains limited. One US study concluded that local and network Spanish-language television stations paid more attention to Latino issues and interests during the 2004 elections but devoted substantially less time to election-related news than English-language outlets overall. Both English- and Spanish-language stations tended to focus more on campaign strategy and horse-race stories than on issues (Hale et al., 2009).

In Canada, Yu and Ahadi (2010) compared political news coverage by English-language and Korean-language newspapers during the 2008 federal campaign. The authors found that the Korean papers increased their political coverage during the election period and also published campaign news that differed from the English-language press: the economy, voter education stories and minority issues were among the top issues covered by the Korean publications while the English-language papers devoted more attention to the election outcome, economy-related stories and government spending/budget issues. The Korean press displayed no overall bias toward a political party and co-existed "with mainstream media while being reasonably connected to and interculturally engaged with broader society" (2010: 67).

$\mathrm{Yu}$ and Ahadi also found that the Korean papers paid special attention to the lone candidate of Korean origin. The extent to which ingroup candidates (candidates from the community served by the newspaper) drive election news coverage, however, has not been explored in any depth. To the extent that these candidates play a role in the amount of election reporting by ethnocultural media, research on the sociology of news may offer some insights as to what is going on. When journalists are pressed to identify the characteristics of newsworthiness, for instance, their list typically includes the potential for conflict or controversy in the story, the timeliness and usefulness of the news, the prominence of the individuals involved, proximity of the issue or event to the audience, likely interest in the story and the potential impact of the news on readers or viewers (McKercher et al., 2011; Zelizer, 2004).

Other theoretical frameworks that have been used to explore the news covered by ethnocultural media can also be applied to the conversations that take place during election campaigns. In its early incarnation, Habermas' concept of the public sphere (1989) was a place where free and open public discourse occurred in the news media and among individuals and groups. The German sociologist's approach came under fire, however, for not recognizing that women, minorities and other groups are often excluded from mainstream civic debates (Fraser, 1993). Subsequent refinements included the idea of numerous "sphericules" that are home to 
"distinct civic discourses not often heard in hegemonic spaces like the mass media" (Karim, 2002: 231). While Yu and Ahadi (2010) did find evidence of a distinct conversation occurring in the Korean press, the extent to which the reporting in the Korean-language newspapers is representative of ethnocultural papers in general merits further investigation.

Finally, election coverage can also be evaluated in terms of Fleras' characterization of ethnocultural news organizations as both "pockets of insularity yet pathways to integration" (2011: 247). Invoking ideas about social capital outlined in Robert Putman's (2001) Bowling Alone, Fleras argues that ethnic media supply a form of bridging capital between groups by championing community interests in public debate and fostering other types of dialogue with the host society. At the same time, he argues, ethnic news organizations also strengthen ties among community members by generating bonding capital in the form of stories that celebrate success, foster cohesion and communicate information that is otherwise unavailable.

News coverage, bias and the Conservative party. Was the CPC's ethnic media strategy during the 2011 election worth the effort? Considerable time and effort has been devoted to investigating mainstream media for evidence of biased reporting during election campaigns (D'Alessio and Allen, 2000). These examinations of partisanship, which has been defined as the "systematic favouring of one party or ideology resulting from the intentional or unconscious biases of reporters, editors, or organizations" (Schiffer, 2006: 24), involve a variety of approaches that can be adapted to evaluate election reporting in the ethnocultural press. D'Alessio and Allen (2000) identified three ways that political bias can creep into news coverage that are potentially applicable. The first, gatekeeping bias, occurs when editors and reporters decide to cover stories about one party while ignoring news about other parties. This type of bias is difficult to assess in that the stories relegated to oblivion are, for the most part, unknowable. A second more readily quantifiable form of partisan news reporting, coverage bias, occurs when one party or candidate receives more media attention than other candidates. The final category, statement bias, deals with actual news content that is more or less favourable to one party or candidate: stories with equal numbers of positive or negative statements or no clearly biased statements, for instance, would be regarded as neutral. Stories dominated by positive or negative statements about one side would be considered overtly biased.

Photographs of politicians have also been investigated for bias because of their power to shape perceptions. The decision, for instance, by Canadian news organizations to use what is now an iconic Canadian Press wire image of Conservative leader Robert Stanfield fumbling a football during the 1974 campaign illustrated the "ability for just one wayward photo to derail a politician's career" (Marland, 2012: 225). On the other hand, 
images of a smiling leader surrounded by happy crowds of supporters contribute to name recognition and positive impressions that can boost support for candidates (Kam and Zechmeister, 2013) and parties (Gassmaier and Marewski, 2011).

Where bias has been identified, questions arise about whether it is intentional, whether it is the result of journalism routines, constraints and norms, or whether it reflects factors on the ground such as a masterful campaign by one side. Schiffer (2006), for instance, points out that journalists' routine reliance upon official sources means incumbents, who tend to have more money, staff and experience in dealing with the media, have an advantage when it comes to using the news media to get their messages out. The degree to which a candidate or party can consistently earn first mention in stories, for instance, is a measure of campaign effectiveness in that it means party strategists are choosing the topic and framing the discussion, leaving the competition to react in later paragraphs. While reporter bias can't be ruled out, data on first mentions provide "valuable information about the relative salience of parties and party leaders during the campaign; they are indicative of the way in which the campaign is being framed, and point to which party or leader is effectively driving coverage" (Andrew et al., 2008: 80).

The potential for advertisers to influence the editorial content of forprofit news organizations (Kovach and Rosenstiel, 2007; Schudson, 2011) may also help explain cases of biased news reporting. Most ethnic news operations are small with limited resources and election advertising purchases by political parties can represent a major revenue stream. Research has shown over the years that news content is not immune from advertiser pressure. Bagdikian (1983), for instance, argued that newspapers did not provide coverage of early studies that linked smoking and cancer because the tobacco companies were major advertisers. A more recent example that points to the vulnerability of small newspapers in particular occurred during local elections in the New York City borough of Queens. In that case, endorsements of candidates by two community newspapers were linked to candidates' purchases of advertisements in the newspapers and consulting fees paid to the papers' affiliated consulting firm (Malo, 2014).

\section{Methodology}

This study examined news about Canada's 2011 federal election in five ethnocultural newspapers published in the GTA with a view to answering the following questions:

- To what extent did the ethnocultural newspapers cover the election and what factors influenced the amount of coverage? 
- Was the coverage different from news coverage provided by mainstream news organizations?

- Did the election news coverage support Fleras' vision of ethnic media as institutions that build bonds within communities while also providing news that helps people integrate with society in general?

- How did the ethnocultural press cover the Conservative Party of Canada?

The content analysis was conducted on issues of the weekly Russian Express, which is published every Friday in Russian, as well as four daily newspapers: Korea Times Daily is a Korean-language newspaper, Canadian Punjabi Post and Punjabi Daily are both published in Punjabi while Ming Pao is published in a traditional unified written Chinese form that is read by both Mandarin and Cantonese speakers. The newspapers were selected because they publish in a language read by a substantial number of people and because, compared to many ethnocultural publications, they have relatively large circulation numbers (Table 1).

For the dailies, coders examined the election coverage that appeared in six issues published between March 25, 2011 (one day before the election call), and May 4, 2011 (two days after the May 2 vote). Coders used constructed week sampling (Monday from the first week, Tuesday from the second week, Wednesday from the third week and so forth) to ensure that content from different days was examined and to avoid over-representation of any particular event. In the case of the weekly Russian Express, six of the seven issues published between March 25, 2011, and May 6, 2011, were coded.

Coders identified election-related advertisements appearing in each newspaper issue as well as the party responsible for the ad and specific ridings (if any) targeted in the advertisement. Election-related editorial content (news and feature stories, columns, editorials, op-ed articles and photographs) was then identified along with each item's origin (whether the item was produced by staff, wire services or came from an unidentified source), the names of specific ridings referenced in each article or photograph and whether the news item focused on just one party.

For news articles, coders also identified the main topic; whether the article dealt with strategy, poll results and other aspects of the horse race or whether it focused on policies and issues; the first party or leader mentioned in the text; and the stance or tone of stories (neutral, positive or negative) based on the existence of critical or favourable statements in the text. Stories that contained no critical or favourable statements regarding a political party were considered neutral as were stories that contained an equal number of critical or favourable statements. Where a party garnered a majority of positive or negative references, it was coded as displaying a leaning or bias vis-à-vis that party. A story with multiple comments critical of a 
TABLE 1

GTA Newspapers

\begin{tabular}{|c|c|c|c|c|c|}
\hline Newspaper & Publishing schedule & $\begin{array}{l}\text { \# of pages per } \\
\text { issue }\end{array}$ & Ownership & Daily circulation $^{1}$ & $\begin{array}{l}\text { GTA population by mother } \\
\text { tongue }^{2}\end{array}$ \\
\hline $\begin{array}{l}\text { Canadian Punjabi } \\
\text { Post }\end{array}$ & Daily Monday to Saturday & $12-20$ & Locally owned/operated & 14,000 to 18,000 & $\begin{array}{l}157,475 \text { residents identified } \\
\text { Punjabi as their mother tongue }\end{array}$ \\
\hline The Punjabi Daily & Daily Monday to Saturday & 16 & Locally owned/operated & 7,500 & \\
\hline Russian Express & Weekly Friday publication & $40-50$ & Locally owned/operated & 14,000 & $\begin{array}{l}78,105 \text { residents identified } \\
\text { Russian }\end{array}$ \\
\hline Korea Times Daily & Daily Monday to Saturday & $22-30$ & $\begin{array}{l}\text { Locally owned with contract to access } \\
\text { content from the U.S. and Korean } \\
\text { editions }\end{array}$ & 15,000 & 51,395 residents identified Korean \\
\hline Ming Pao & Seven days per week & 80 & $\begin{array}{l}\text { Owned by a foreign-based } \\
\text { multinational }\end{array}$ & 51,000 & $\begin{array}{l}\text { 427,685 residents identified a } \\
\text { Chinese language }\end{array}$ \\
\hline
\end{tabular}

${ }^{1}$ Circulation data supplied by newspapers

${ }^{2}$ Statistics Canada. 2012. 
candidate accused of making a racist remark, for instance, would be coded as negative for that party (anti-Liberal or anti-Conservative for example) if critical statements outnumbered statements in defence of the candidate.

In the case of photographs, coders identified the individuals in photographs (party leader, party candidate and so forth). Photos containing images of political leaders or candidates were also categorized as either neutral/positive or negative. Negative images were those that were judged to be unflattering or that showed a politician looking angry, speaking to a mostly empty room, or in an awkward physical position. Neutral and positive images were those that showed a politician as earnest, passionate, confident, happy or smiling or among cheering supporters.

Four coders who spoke English as well as Korean, Punjabi, Russian or Mandarin gathered the data. Resource constraints meant one rather than two coders coded the editorial content of each newspaper. In light of this, the issue of intercoder reliability was addressed by having all the coders practise and complete an intercoder reliability test using 2011 election content from three English-language newspapers. The coders received about 20 hours of training using 40 election-related stories and photographs from the Toronto Star, National Post and Globe and Mail newspapers. Once random testing showed they were coding in a consistent manner, the coders completed an intercoder reliability test consisting of election items from the English-language papers. Intercoder reliability for each variable was measured using Cohen's Kappa, with the aid of PRAM (Program for Reliability Assessment with Multiple Coders) software. Cohen's Kappa is a relatively conservative index that measures the extent to which coders make identical coding decisions, and takes into account the agreement expected by chance. For more than two coders, values of between .400 and .75 may be taken to represent fair to good agreement beyond chance (Banerjee et al., 1999; Fleiss, 1981; Landis and Koch, 1977). Intercoder reliability was at or above 0.68 for all variables. Based on this result, coders' decisions for the respective ethnocultural newspapers were considered to be generally consistent and accurate. Detailed results of the intercoder reliability test are available in Appendix A.

Since language ability was not required to assess photo tone and because making judgments about images is particularly subjective, two coders assessed all the photographs of politicians and categorized them as either neutral/ positive or negative. The coders were trained using photographs from the ethnic newspapers and then successfully completed an intercoder reliability test involving a selection of photographs that were also drawn from the sample publications. They achieved perfect (1.0) agreement where a photo contained only one politician and agreement of .743 in cases where they assessed the tone for politicians from multiple parties who appeared in the same photograph (see Appendix A for details). After completing the test, they shared responsibility for coding the rest of the photographs. 


\section{Findings and Discussion}

To what extent did the ethnocultural newspapers cover the election and what factors influenced the amount of coverage? The five newspapers contained a total of 390 election-related items consisting of 179 text items (165 news/feature stories, one op ed piece by a candidate, eight columns and five editorials) and 211 photographs. The balance between photos and stories was roughly equal in three of the dailies (Table 2). Russian Express was an outlier in that it carried twice as many articles as photographs. The Punjabi Post also stood out, but for the opposite reason-in its case photos outnumbered stories more than two to one. The Post's layout offers one possible explanation for this imbalance: the paper has an oldfashioned look and uses a lot of relatively tiny photographs. More modern layouts use fewer images that are much larger. The paper's small newsroom staff may also help explain the preponderance of photos; in these digital times, photographs are easy to obtain from people who attend events and also from party websites, press releases and social media (Marland, 2012). Finally, while a reporter covering an event may only have time to produce a single story, the same reporter can shoot multiple photographs for publication.

There was no consistent pattern among the newspapers when it came to horse-race versus issue-based stories. The Punjabi-language newspapers produced content that was similar to mainstream election news coverage in that stories about election strategy, poll results and other aspects of the horse race appeared much more frequently than stories about issues. The Daily's coverage featured 44 stories focused on the horse race and 24 issues-related articles, while the Post ran 24 items about who was winning and losing and just seven stories dealing with issues. The horserace focus in these papers reflects a well-documented industry-wide news culture that values conflict, variety and a compelling storyline, in this

TABLE 2

Number of Election-related Stories and Photographs

\begin{tabular}{lccccc}
\hline \hline & $\begin{array}{c}\text { Korea } \\
\text { Times } \\
\text { Daily }\end{array}$ & Ming Pao & $\begin{array}{c}\text { Punjabi } \\
\text { Daily }\end{array}$ & $\begin{array}{c}\text { Punjabi } \\
\text { Post }\end{array}$ & $\begin{array}{c}\text { Russian } \\
\text { Express }\end{array}$ \\
\hline $\begin{array}{c}\text { Total news items } \\
\text { published during } \\
\text { the study period }\end{array}$ & 862 & 3277 & 377 & 529 & 323 \\
$\begin{array}{c}\text { Total number of election } \\
\text { stories and photos }\end{array}$ & $49(5.7 \%)$ & $94(2.9 \%)$ & $123(32.6 \%)$ & $105(19.8 \%)$ & $19(5.9 \%)$ \\
$\begin{array}{c}\text { Election-related stories } \\
\text { Election-related photos }\end{array}$ & $23(2.7 \%)$ & $44(1.3 \%)$ & $68(18.0 \%)$ & $31(5.9 \%)$ & $13(4.0 \%)$ \\
\hline
\end{tabular}


instance one that portrays candidates as strategists who are pursuing a winning (or losing) campaign. By comparison, Iyengar and colleagues have observed, "analysis of the candidates' competing policy visions is stale and repetitive. Unlike most aspects of the campaign, which are stage-managed and predictable, the horse-race story often strays from the script, thus providing additional daily news value" (2004: 159). Horserace news, they added, is also "widely available for the simple reason that it attracts readers and viewers" (173).

That said, Ming Pao strayed from the norm by publishing more issueand-policy related stories (31) and just 13 horse-race stories. Future research involving interviews with Ming Pao editors would be useful in terms of understanding why the paper deviated from the norm and whether this was a deliberate strategy. The number of issue versus horse-race stories was relatively balanced in the remaining two papers; in Russian Express there were seven stories dealing with issues, six about the horse race and in Korea Times Daily, 10 stories on issues while 13 focused on the horse race.

In terms of the overall amount of election coverage, the Punjabi Daily (123 stories and photos) and Canadian Punjabi Post (105 stories and photos) offered the most election-related content according to a variety of measures. Election news accounted for 32.6 per cent and 19.8 per cent, respectively, of all news items published over six issues. The Daily published an average of 20.5 election news items per issue while the Post averaged 17.5 news items. Ming Pao also devoted significant attention to the campaign, publishing 94 election-related items or an average of 15.7 stories and photographs per issue. This amounted to only 2.9 percent of total news content, however, because of the high number of news items published by the paper each day (Table 2). Korea Times Daily (49 electionrelated items representing 5.7 per cent of total news content) published an average of 8.2 election-related items per issue, while election coverage in Russian Express (19 items representing 5.9 per cent of all news content) was much more limited with about three election items per issue (Table 2).

What explains this variation? The data offer some insights. The first is that newsroom size did not appear to be a determining factor. Russian Express, which published the least campaign coverage, is the smallest operation with just four staff. Canadian Punjabi Post is slightly larger, employing six local reporters and editors, yet it carried more than five times the election news. Ming Pao, meanwhile, with more than two dozen reporters, editors and photographers, also published fewer electionrelated items than its much smaller Punjabi-language counterparts.

Commitment to election coverage did seem to be influenced, however, by the number of ingroup candidates drawn from a newspaper's readership community (Table 3 ). The most extensive election reporting was in the Punjabi-language papers, which had at least 10 ingroup candidates to 
TABLE 3

References to Local Ridings in Ethnocultural Newspapers

\begin{tabular}{lcccc}
\hline \hline & $\begin{array}{c}\text { \# of ingroup } \\
\text { candidates in } \\
\text { GTA }^{1}\end{array}$ & $\begin{array}{c}\text { \# of items } \\
\text { referencing GTA } \\
\text { ridings with ingroup } \\
\text { candidates }^{2}\end{array}$ & $\begin{array}{c}\text { \# of items that } \\
\text { make no riding } \\
\text { references }\end{array}$ & $\begin{array}{c}\text { \# of items that } \\
\text { reference other } \\
\text { ridings }^{3}\end{array}$ \\
\hline Korea Times Daily & 0 & 0 & 35 & 14 \\
Ming Pao & 5 & 17 & 64 & 13 \\
Punjabi Daily & 10 & 24 & 92 & 7 \\
Punjabi Post & 10 & 33 & 66 & 6 \\
Russian Express & 0 & 0 & 19 & 0 \\
\hline
\end{tabular}

${ }^{1}$ Siemiatycki, 2011b and author's data

${ }^{2}$ See Appendix 2 for detailed breakdown of ridings and ingroup candidates.

${ }^{3}$ GTA ridings with no ingroup candidates and ridings outside the GTA.

cover in the GTA (Siemiatycki, 2011b; author's data). Indeed, in two ridings (Brampton-Springdale and Bramalea-Gore-Malton) the candidates for all three major parties were of Punjabi origin. The Punjabi Daily's coverage included 24 news items containing 31 references to GTA ridings (some stories and photos referenced more than one local riding) where one or more Punjabi candidates were in the running. The Punjabi Post published 33 items that contained 52 references to GTA ridings with ingroup candidates. The focus on ridings with a candidate from the newspaper's target audience was also evident, though less pronounced, in election coverage by Ming Pao, which had five local GTA candidates of Chinese origin (Siemiatycki, 2011b) to write about: it published 17 news items containing 17 references to GTA races involving Chinese candidates.

By comparison, Russian Express, which did not have a community member running in the election, mentioned no specific GTA riding or any other riding for that matter; all of its limited coverage dealt with the national campaign. The Korea Times Daily, which also had no local candidates of Korean origin to write about, did publish 14 news items referencing specific ridings but some of this coverage was devoted to three races in other parts of Canada where candidates of Korean origin sought office. In the GTA, its coverage included five news items that focused on the contest in the riding of Willowdale, where about 8 per cent of the riding's population is of Korean origin (Statistics Canada, 2008). A story headlined "Interview with 3 Candidates in Willowdale, the Most Korean District" (2011: A1), makes plain the reasons the race was of interest to the newspaper's readership. A detailed breakdown of references to specific ridings and in group candidates can be found in Appendix B.

It is important to note that in all five newspapers, the majority of coverage actually focused on the race in general rather than on specific ridings (Table 3). Coverage of local races involving ingroup candidates, however, 
clearly boosted the total amount of election reporting and may have encouraged coverage of the race in general since local candidates' prospects are often closely tied to the fate of the national leader and campaign.

Editors' decisions to cover races involving ingroup candidates are consistent with journalists' definitions of what is newsworthy. Conflict and controversy are inherent in election campaigns and there was ample drama in these local races, as Ming Pao suggested in a headline that said "Battle fierce in Trinity-Spadina, Christine Innes fighting Olivia Chow" (2011: A2). Coverage of ingroup candidates passed other tests of newsworthiness in that it furnished useful, timely information to voters about prominent individuals vying to represent them. Proximity as a factor in determining editors' story assignment decisions was particularly striking in the case of the Punjabi-language newspapers: both publications are located in the Brampton area, where South Asians made up about one-third of all residents in the hotly-contested ridings of Brampton-Springdale and neighbouring Bramalea-Gore-Malton (Statistics Canada, 2008).

Finally, races in ridings with ingroup candidates are newsworthy because the results have the potential to shape the extent to which voters feel their interests are represented. The Punjabi-speaking NDP candidate in Brampton-Springdale, for instance, told voters he would make immigration and seniors issues his top priority if elected ("Immigration and Senior Citizen Issues," 2011). More generally, a study of debates in Canada's House of Commons found that members of Parliament from visible minority groups are more likely than non-minority MPs from highly diverse ridings to address ethnic-related issues (Bird, 2007).

Was the coverage different from news coverage provided by mainstream news organizations? Election reporting in the ethnocultural newspapers was unique in several respects. In the first instance, the papers provided readers with news about ridings with ingroup candidates that was not readily available elsewhere. Table 4 compares the number of news items that mentioned ridings with ingroup candidates to the number of times the same ridings were referenced in the Toronto Star, the Toronto-area's largest daily. The Star data, obtained by searching the riding names in the Proquest Newsstand database, were collected for all 41 days between March 25, 2011, and May 4, 2011.

The comparison shows that all of the ethnocultural newspapers except Russian Express, which mentioned no electoral districts by name in any of its reporting, provided more intensive coverage of races of interest to their respective readerships. The riding of Brampton-Springdale, for instance, was referenced in 13 news items over just six days in each Punjabi-language newspaper (approximately 2.2 mentions per issue). During the 41 days of Star coverage, it was mentioned in a total of 23 news articles (approximately 0.6 mentions per issue). Similarly, Ming Pao mentioned the riding of 
TABLE 4

Riding References: Toronto Star vs. Ethnocultural Newspapers

\begin{tabular}{|c|c|c|}
\hline $\begin{array}{l}\text { GTA ridings (with ingroup } \\
\text { candidates) mentioned in } \\
\text { ethnocultural newspapers }\end{array}$ & $\begin{array}{l}\text { Ethnocultural newspaper: } \\
\# \text { of news items with } \\
\text { riding reference }\end{array}$ & $\begin{array}{l}\text { Toronto Star: } \# \text { of news } \\
\text { items with riding } \\
\text { reference }{ }^{2}\end{array}$ \\
\hline Brampton-Springdale & $\begin{array}{l}13 \text { (Punjabi Post) } \\
13 \text { (Punjabi Daily) }\end{array}$ & 23 \\
\hline Bramalea-Gore-Malton & $\begin{array}{l}13 \text { (Punjabi Post) } \\
7 \text { (Punjabi Daily) }\end{array}$ & 8 \\
\hline Brampton West & $\begin{array}{l}6 \text { (Punjabi Post) } \\
7 \text { (Punjabi Daily) }\end{array}$ & 18 \\
\hline Etobicoke North & $\begin{array}{l}12 \text { (Punjabi Post) } \\
1 \text { (Punjabi Daily) }\end{array}$ & 5 \\
\hline Mississauga-Brampton South & $\begin{array}{l}8 \text { (Punjabi Post) } \\
3 \text { (Punjabi Daily) }\end{array}$ & 5 \\
\hline Trinity-Spadina & 13 (Ming Pao) & 17 \\
\hline Markham-Unionville & 4 (Ming Pao) & 3 \\
\hline Willowdale $^{3}$ & 5 (Korea Times Daily) & 2 \\
\hline
\end{tabular}

${ }^{1}$ Published on six sample days

${ }^{2}$ Published from March 25-May 4, 2011 (41 days)

${ }^{3}$ No ingroup candidate but the riding was of interest to Korea Times Daily readers because it is home to a concentration Korean Canadians.

Trinity-Spadina in 13 news items over six issues while the Star mentioned the same riding just 17 times during the entire March 25, 2011, to May 4, 2011, period.

The Star data may be somewhat understated because the Proquest Newsstand search would not have identified riding-related photographs if the riding name was not mentioned in the information cutline. Assuming that the Star ran a photo with every story, however, it would still have lagged behind the ethnocultural press. With the numbers doubled, for instance, the Star would still only have referenced Brampton-Springdale in an average of 1.1 news items per issue.

The ethnocultural papers also created space for a distinct civic discourse in terms of the news they covered. Item topics were assigned to text articles only. To confine the analysis to the actual campaign period, Figure 1 shows the most common topics in stories published up to and including voting day on, May 2, 2011, and (in this case only) does not include 32 post-election stories that dealt mostly with winners and losers.

A comparison of the top issues reported on by mainstream and ethnocultural publications points to only a limited overlap in terms of topics (Table 5). Data collected by McGill's Institute for the Study of Canada on topic key words in English-language news articles at the beginning and end of the 2011 campaign identified the economy, foreign affairs, taxes, and crime and justice as the most frequent themes (Soroka et al., 
FIGURE 1

Top issues in ethnocultural newspapers with headline examples

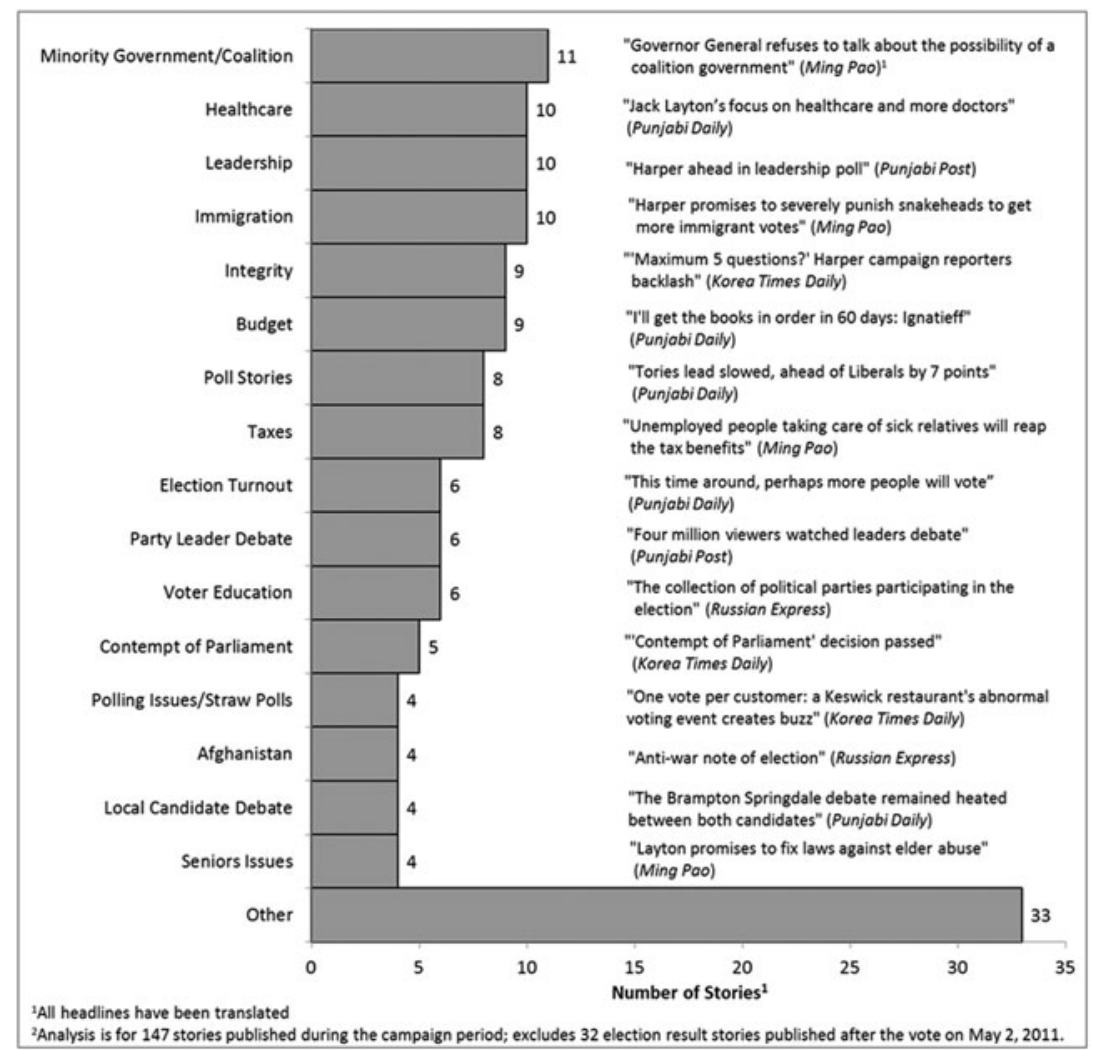

2011). Coverage did overlap in that campaign news about taxes and the related topic, the federal budget, emerged as prominent issues in the five ethnocultural newspapers. Ming Pao, for instance, published stories with headlines such as "Worried about Scaring Away Investment, Business Appeals to Not Have Corporate Tax Cuts Taken Away," (2011: A11) while the Punjabi Daily's budget-related coverage included a story with the headline "I'll Get the Books in Order in 60 Days: Ignatieff" (2011: 1).

Within the ethnocultural "sphericules" (Karim, 2002), however, issues related to minority and coalition government, leadership, healthcare and government integrity were considered the most newsworthy. The emphasis on minority government and coalition issues is noteworthy in that attacking the opposition parties on this issue (with particular emphasis on the spectre of a separatist Bloc Québécois as part of a coalition) was an important part 
TABLE 5

Election Topics

\begin{tabular}{|c|c|c|c|}
\hline \multirow[b]{2}{*}{ Rank } & \multicolumn{2}{|c|}{ English-Language Media ${ }^{1}$} & \multirow{2}{*}{$\begin{array}{c}\text { Ethnocultural Media }{ }^{2} \\
\text { Election Campaign Period }\end{array}$} \\
\hline & Week 1 & Week 5 & \\
\hline 1 & Economy & Foreign Affairs/Defence & Minority Government/Coalition \\
\hline 2 & Foreign Affairs/Defence & Economy & $\begin{array}{l}\text { Immigration; Leadership; } \\
\text { Healthcare }\end{array}$ \\
\hline 3 & Taxes & Crime/Justice & Budget; Integrity \\
\hline 4 & Crime/Justice & Education & Taxes; Poll Stories \\
\hline 5 & Education & Employment/Labour & $\begin{array}{l}\text { Voter Education; Local Candidates' } \\
\text { Debate;Election Turnout }\end{array}$ \\
\hline 6 & Employment & Taxes & Contempt of Parliament \\
\hline
\end{tabular}

${ }^{1}$ Source: Soroka, Cutler, Stolle \& Fournier, 2011.

${ }^{2}$ Excludes election-result stories published after May 2.

of the Conservative campaign strategy (Wells, 2013b). The results suggest journalists working for ethnic media may have more readily embraced the Conservative messaging on this issue than their mainstream counterparts from the Ottawa press gallery. Immigration and voter education storiestopics clearly relevant to many immigrant readers - also received more attention in the ethnocultural press than in mainstream news coverage.

While differences in coding methodologies may explain some variations in the two news agendas, the findings are consistent with $\mathrm{Yu}$ and Ahadi's (2010) earlier study of English- and Korean-language media coverage of the 2008 election in Vancouver-area newspapers. In that case, researchers also identified stories about voting rules as a key topic and concluded overall that "there was a distinction between mainstream and ethnic media in that ethnic media were sufficiently connected to broader society to cover the election, but largely distinct in the overall communication system so as to focus on the agenda of their own interests separate from that of English media" (60).

Did the election news coverage support Fleras' vision of ethnic media as institutions that foster bonds within communities while also providing news that helps people integrate with society in general? The answer to this question depends on which newspaper is being considered. All of the publications focused at least two-thirds of election news on the overall race rather than local contests (Table 3): 75 per cent or 92 of 123 election stories and photos in the Punjabi Daily dealt with the national race with no references to specific GTA or other ridings; general election coverage accounted for 63 per cent of items (66 out of 105 items) in Canadian Punjabi Post; 68 per cent of items (64 out of 94) in Ming Pao; and 71 per cent of election-related items (35 of 49) in Korea Times Daily. All 
the election-related content in Russian Express dealt with the national race (Table 3). This suggests readers had access, albeit to varying degrees, to general election information or "bridging capital" (Fleras, 2011: 246) that would equip them to engage with broader society on a matter of national importance. Information on everything from polling data and the parties' various platform planks to the leadership debates and the potential for a coalition government received attention (Figure 1). This type of coverage supports integration in that informed citizens are "more likely to participate in politics, more likely to have meaningful, stable attitudes on issues, better able to link their interests with their attitudes, more likely to choose candidates who are consistent with their own attitudes, and more likely to support democratic norms" (Delli Carpini, 2000: 157).

At the same time, coverage of ingroup candidates by the Punjabi-language newspapers and Ming Pao provided a form of "bonding capital" (Fleras, 2011: 246), potentially contributing to the formation of community ties by highlighting ingroup candidates' achievements and election involvement and telling stories otherwise unavailable to readers. In this sense, the newspapers were, in Fleras' words, "supplying information of relevance and immediacy to the intended demographic" (245).

How did the ethnic press cover the Conservative Party of Canada? The editor of the Brampton, Ontario-based South Asian Focus newspaper observed during a post-election forum on elections and the ethnic vote that reaching out to ethnocultural news media was a key element of the Conservative campaign strategy. The party, Sunil Rao said, "had a system in place, they had the grassroots networks to be able to connect to small papers like ours ... we were kept in the loop" ("Elections," 2011). Was this media strategy effective in terms of generating favourable coverage for the governing Conservatives?

If statement bias is the only measure of media partisanship considered, the CPC's charm offensive produced only limited results. Stories dominated by positive or negative statements about one party were relatively rare, with all nine news articles that revealed a clear bias appearing in the Punjabilanguage newspapers. No single party emerged as a clear favourite in the Punjabi Post, which published one column where the majority of statements favoured the NDP and a second editorial that favoured the Conservatives.

The Punjabi Daily published the other seven articles that displayed partisan leanings, including five that suggested a pro-Liberal, antiConservative stance. One of the two pro-Liberal items was a story that lavishly praised the party's candidate in the riding of Bramalea-Gore-Malton, noting that incumbent Gurbax Malhi (who was defeated) is "so smart and has such a pure heart that no one could prevent this diamond from shining" ("Government of Heart," 2011: 16). The three articles critical of 
the Conservatives included an op-ed piece by a Liberal candidate that urged Prime Minister Harper to "stop going back on your statements and step down from your high pedestal" ("An Open Offer," 2011: 9). In another case, an editorial chastised Harper for not attending Sikh parades in Surrey, BC, and Toronto, a decision that the newspaper editorialist observed "displays a negative picture about him" ("He Made Several Trips," 2011: 4). It is important to note that while there were five articles indicating a bias against the governing party, 90 per cent of the paper's 68 election-related stories were neutral in tone.

The absence of extensive statement bias in the ethnocultural newspapers overall is not so surprising, given that fact-based news and feature stories accounted for almost all news articles - all the papers combined published a total of only 14 op-ed items, columns and editorials. Researchers who have coded for tone in campaign coverage by the mainstream news media have observed that editorials and op-ed pieces, which by definition are expressions of opinion, are much more likely than straightforward news accounts to convey positive or negative sentiments (Soroka et al., 2009). The focus on news and feature stories that are generally neutral in tone as opposed to opinion pieces characterized by a distinctive viewpoint was consistent with what Yu and Ahadi (2010) found in their study of election coverage by Vancouver's Korean press.

The data on coverage bias, however, tell a somewhat different story in terms of how the Conservatives fared on the pages of the ethnocultural newspapers. Analysis of the amount of coverage accorded the parties in most cases found the CPC tended to garner the most attention. This would have been problematic if the coverage had been negative but, as the earlier data on statement bias indicates, the vast majority of reporting was neutral in tone. Under such circumstances, getting the message out through the media more effectively and extensively than the competition was a definite advantage because, as Nadeau and colleagues have argued, "political parties and leaders have a powerful incentive to inform voters about their positions on the issues of the day" (2008: 229). The powerful incentive, they go on to show, is that campaign messages have the potential to change vote intentions, particularly among citizens who start out as moderately informed.

Coverage bias was evident in that the CPC tended to be the most frequent subject of news items featuring a single party in all of the newspapers. This tendency, which clearly constitutes an advantage in that the news items contained no competing messages to sway voters, was particularly evident in text articles in all publications (Table 6). It was also clearly the case for photographs in three of the newspapers. The number of photos featuring just one party was more balanced in Ming Pao while the Punjabi Daily treated the Liberals and Conservatives (but not the NDP) relatively evenhandedly. 
TABLE 6

Election Stories and Photos that Reference Only One Party

\begin{tabular}{|c|c|c|c|c|c|}
\hline & $\begin{array}{l}\text { Korea Times } \\
\text { Daily }\end{array}$ & $\begin{array}{l}\text { Ming } \\
\text { Pao }\end{array}$ & $\begin{array}{c}\text { Punjabi } \\
\text { Daily }\end{array}$ & $\begin{array}{l}\text { Punjabi } \\
\text { Post }\end{array}$ & $\begin{array}{l}\text { Russian } \\
\text { Express }\end{array}$ \\
\hline \multicolumn{6}{|c|}{ Stories that reference only one political party and percentage by party } \\
\hline $\begin{array}{l}\text { \# of stories that reference } \\
\text { only one party }\end{array}$ & 3 & 9 & 17 & 11 & 2 \\
\hline Conservative & $100 \%$ & $67 \%$ & $76 \%$ & $45 \%$ & $100 \%$ \\
\hline Liberal & $0 \%$ & $11 \%$ & $24 \%$ & $36 \%$ & $0 \%$ \\
\hline NDP & $0 \%$ & $22 \%$ & $0 \%$ & $18 \%$ & $0 \%$ \\
\hline Other & $0 \%$ & $0 \%$ & $0 \%$ & $0 \%$ & $0 \%$ \\
\hline \multicolumn{6}{|c|}{ Photos that reference only one political party and percentage by party } \\
\hline $\begin{array}{l}\text { \# of photos that reference } \\
\text { only one party }\end{array}$ & 16 & 39 & 45 & 44 & 5 \\
\hline Conservative & $38 \%$ & $31 \%$ & $38 \%$ & $45 \%$ & $80 \%$ \\
\hline Liberal & $25 \%$ & $28 \%$ & $40 \%$ & $34 \%$ & $20 \%$ \\
\hline NDP & $19 \%$ & $36 \%$ & $16 \%$ & $16 \%$ & $0 \%$ \\
\hline Other & $19 \%$ & $5 \%$ & $7 \%$ & $5 \%$ & $0 \%$ \\
\hline
\end{tabular}

Conservatives (candidates or the party leader) also appeared more frequently than politicians from other parties in photographs published by the Punjabi Post, Korea Times Daily and Russian Express (Figure 2). Liberals were featured most frequently in the Punjabi Daily, while Ming Pao's coverage, once again, tended to be more balanced. While images can send negative messages about politicians and potentially influence voters (Barrett and Barrington, 2005), the data show this was not something the Conservatives had to worry about: 96.8 per cent of all photos of Conservative politicians captured in the data set were neutral or positive (as were 94.3 per cent of Liberal images and 100 per cent of photos of New Democrats). In the absence of unflattering, negative images, the extent to which Conservatives dominated photographic content in the individual newspapers was a "win" for the party because, as Marland suggests, there is considerable evidence that "a positive nonverbal image is related to leaders' popularity and power" (2012: 218). More such images, therefore, are more of a good thing.

Finally, in all five newspapers, the Conservatives consistently garnered the most first mentions in stories although this was another case where the tendency was least pronounced in Ming Pao (Figure 3). It is important to note that the Conservatives also dominated first mentions in campaign coverage by English- and French-language newspapers (Soroka et al., 2011), which suggests the party enjoyed considerable success across the entire media spectrum when it came to setting the campaign agenda. Being mentioned first in stories was also likely a benefit of incumbency and consistent with what researchers have recognized as "an underlying equilibrium 
FIGURE 2

Photo appearances of individuals by political party

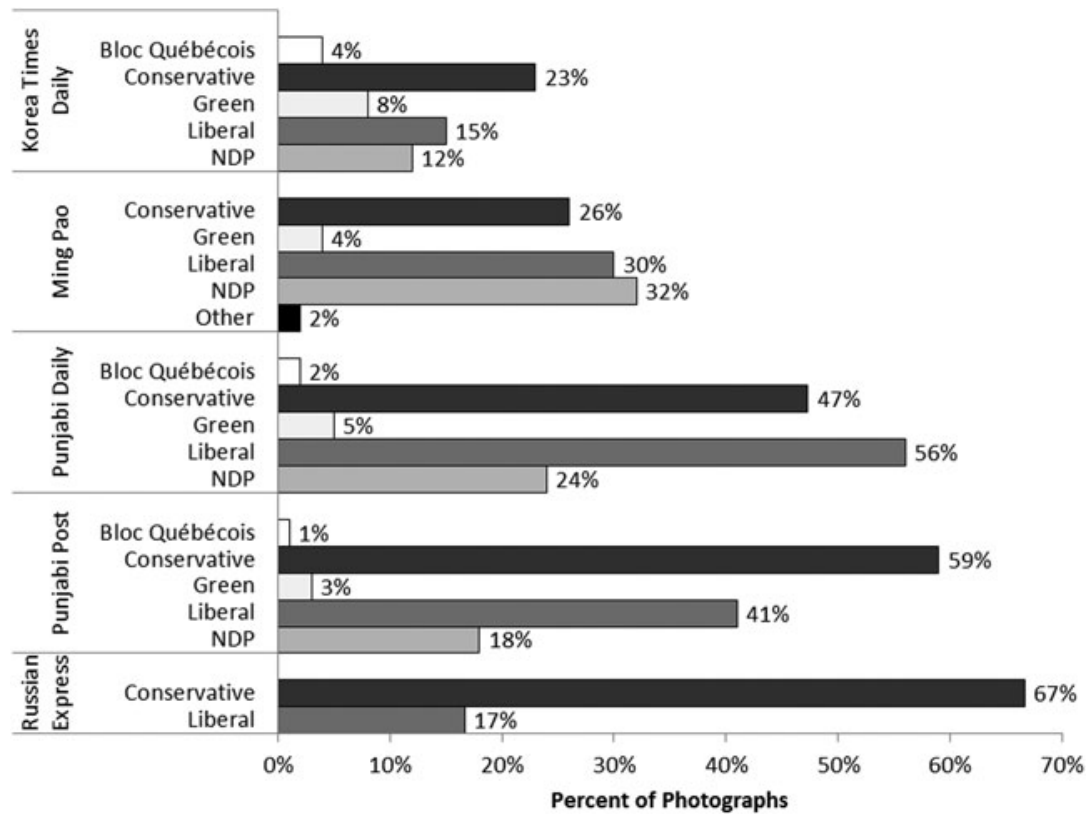

between the amount of coverage a party receives and its political support" (Jenkins, 1999: 429).

The journalism practices of the ethnocultural newspapers offer some possible explanations for the edge Conservatives enjoyed in terms of first mentions and the amount and type of coverage the party received. To varying degrees, for instance, the papers published stories and photographs of unknown origin. Ming Pao carried the smallest proportion of news items (11 per cent of stories and 34 per cent of photos) that provided no indication as to their source. At the other end of the spectrum, no information was provided on the origin of any of the 19 election items published by Russian Express or for any of the photographs that appeared in the two Punjabi-language newspapers. Additionally, coders were unable to determine the origins of 29 per cent of news articles in the Punjabi Post and 41 per cent of articles in Punjabi Daily. In Korea Times Daily, almost all photographs (24 of the 26 photos) and about two-thirds or 16 of the 23 news articles were of unknown provenance.

Small news operations with only limited resources and training in journalism standards may not recognize the extent to which providing information on the origin of photographs and other content helps avoid perceptions 
FIGURE 3

Which party, party candidate or leader was mentioned first in election stories?

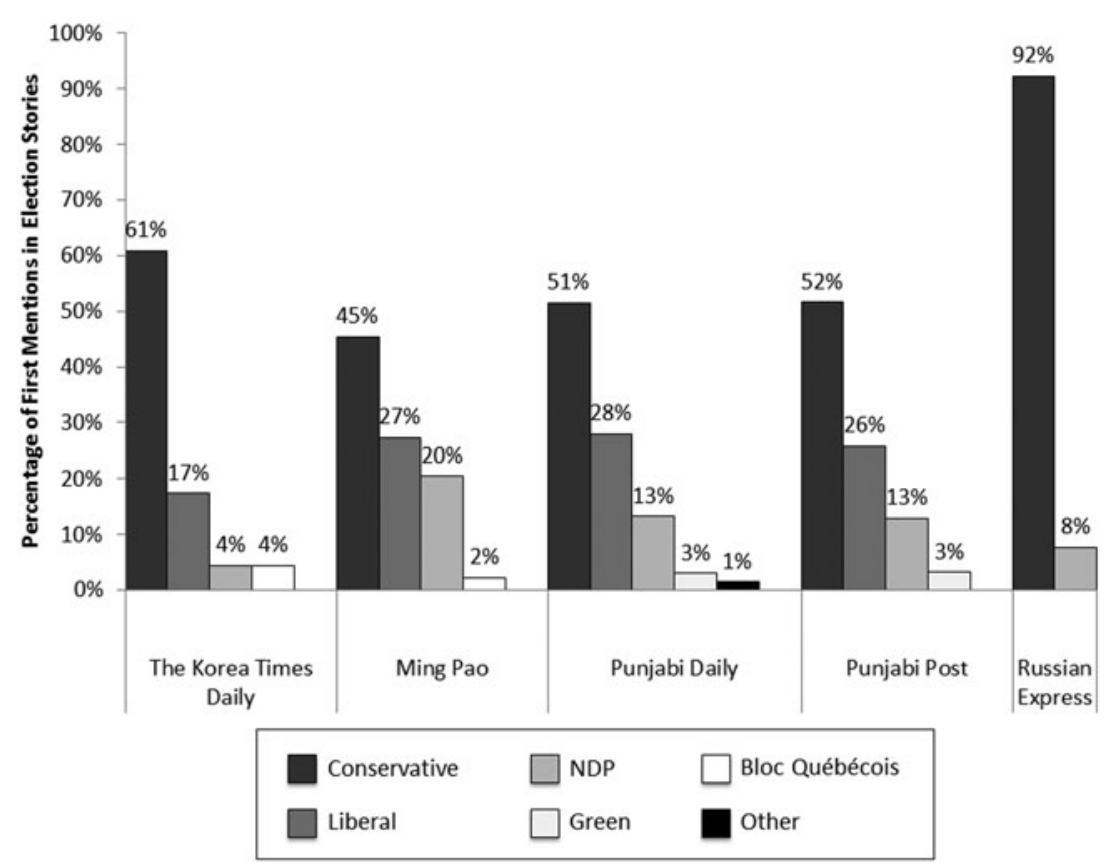

of bias. Failure to identify the source of news items prompts speculation that the papers "borrowed" material from mainstream news organizations, thereby importing their tendency to mention the Conservatives first in stories (Soroka et al, 2011). Lack of information on item origin also raises questions about the extent to which the papers used materials supplied by political handlers seeking to control their candidates' image by making flattering content easily accessible to the media. Marland noted, for instance, that the Conservative party offered an extensive photo gallery of positive Harper images to media outlets through social media and the party website during the 2011 election. "The Harper team," he noted, "targets its preferred elector segments by narrowcasting to small news operations run by two to three people, particularly ethnic media, and via the Internet" (2012: 221).

Faced with major time and financial constraints, smaller news organizations in particular welcome the free content. "[We have] virtually no budget for content. Since we have very little money for photographs, we do make use [of] any content made available at no cost even if it comes 
from official sources, raising questions about objectivity," one editor of a small news outlet has acknowledged (Marland, 2012: 226). To the extent that the Conservatives put in place the most effective machinery for distributing materials to news organizations, they may have succeeded in getting more uncritical, extensive coverage of their candidates and the leader. This must be considered a possibility in the absence of source information for so many of the news items that appeared in the ethnocultural publications.

The business models of newspapers - in particular, their reliance upon advertising revenue - also pose a potential threat to fair, unbiased news coverage if the firewall between the advertising and news departments is breached. All but one of the 41 advertisements by political parties appeared in the two Punjabi-language newspapers and they focused most frequently on the ridings of Bramalea-Gore-Malton and BramptonSpringdale, the ridings where all three leading parties ran candidates of Punjabi background.

The parties placed roughly the same number of ads in the Punjabi Daily (six Conservative ads, four Liberal ads, and five NDP ads), which the data analysis shows was not quite as firmly in the Conservative camp as the Punjabi Post. The Post, on the other hand, published more Conservative advertisements (13) than the Liberals (eight) and the NDP (four) combined. Did advertising dollars influence the Post's news reporting? While the newspaper did publish one editorial supporting the Conservatives, there was no overwhelming evidence of statement bias in its news stories. The CPC did, however, fare much better than its competitors according to other partisanship indicators: Conservative party representatives appeared more often in photographs than their counterparts from other parties; the paper published more stories and photos featuring just Conservative party sources; and the Conservatives dominated first mentions in stories.

Punjabi Post editor Jagdish Grewal was unapologetic about the potential for advertisers to influence his newspaper's content: "[Advertising] is where we get the revenue from and we cannot go against the people who are giving us the revenue. We are not at that point yet," he told a reporter (Bascaramurty, 2013). It's important to note, however, that the Conservatives also enjoyed more favourable coverage in Russian Express and Korea Times Daily and neither of these newspapers carried any party advertisements at all.

The CPC advantage in the Korean, Russian and Punjabi newspapers most likely resulted from a combination of factors. The Conservatives likely benefited in terms of coverage because they were the governing party and because they generally polled ahead of the other parties. Journalistic bias may have played a role. The fact that the Conservative party was a major advertiser in the Punjabi Post may have resulted in more party coverage. Finally, the impact of a highly effective 
Conservative campaign, a campaign that among other things made the party leader, candidates and prepackaged digital images and stories more accessible to journalists from small ethnic news organizations with limited resources and training, cannot be ruled out as a factor that contributed to more extensive coverage of the Conservatives in the three papers.

Ming Pao's somewhat more balanced election coverage deserves special mention in that it suggests more even-handed reporting practices are possible within the ethnic media sector. While the newspaper did cite the Conservatives most frequently when it came to first mentions in stories, the tendency was somewhat less pronounced than in the other publications. The Chinese-language newspaper also stood out because it provided relatively equal coverage of all three leading political parties in terms of photographs that featured only a single party or candidate and in terms of the number of times politicians from each party appeared in photos. Ming Pao is, however, a considerably larger news operation than its four counterparts and this may translate into more professional reporting standards, including journalists' awareness and commitment to fairness and transparency in election coverage.

\section{Conclusion}

Events since the 2011 federal election suggest that the CPC is not alone in recognizing the importance of ethnocultural news outlets for communicating with key groups of voters. Taking a page from the federal party's playbook, the governing Liberals in British Columbia developed an ethnic outreach strategy going into the spring 2013 provincial election, one that devoted significant attention to ethnocultural news media. "We need to redefine our approach to ethnic media from being an 'add-on' to being viewed as part of the mainstream media," the authors of the strategy observed in a document obtained by news media (Dyble, 2013: 44). They went on to argue for a more prompt response to calls from journalists working for ethnic media, the hiring of more people who speak key languages and the establishment of a "stable of supporters willing to write letters to the editor or call in to open-line shows to aid in both supporting our proactive efforts in non-English media and responding to attacks" (44).

The federal Conservative party, meanwhile, continues to reach out to voters through ethnic media between campaigns. In late 2013, the party went to air with a hard-hitting Punjabi-language advertisement attacking Liberal leader Justin Trudeau's call for more relaxed marijuana laws. The ad prompted one Vancouver supporter of Trudeau's proposal to tweet that there is a "big \& growing immigrant community from strict anti-drug-use countries, so Harper Cons targeting them" (Wells, 2013a). 
Journalists from ethnocultural news outlets welcome the attention they are attracting in political circles. They note that governments regularly monitor mainstream English- and French-language news reporting and suggest that recent efforts to track ethnic media content and court journalists from ethnic news organizations make voters in those communities feel part of the political process (Meyer, 2010). The cumulative effect, they argue, is a long overdue acknowledgement that ethnic voices, views and issues matter (Cheadle and Levitz, 2012b).

While exploring the impact of election coverage on civic engagement was outside the parameters of this study, the research addresses the issue indirectly in that access to information is an important starting point for meaningful engagement. In that context, the findings offer a number of insights. First, they are a cautionary tale about making general claims respecting election coverage in ethnic newspapers. Some newspapers offer their readers a range of election news. Others offer them little.

Among the publications that make an effort to carry campaign coverage, the majority of the reporting is about the race in general, dealing with topics ranging from party promises to the latest poll results. In making such news available, the ethnocultural newspapers provide essential bridging capital for readers who want to participate in a major national political event. The papers also have the potential to strengthen bonds among community members by providing information on issues of interest and covering ingroup candidates who are important for what they represent to their communities: a reduced sense of marginalization, an increased sense of belonging and assurances that those who govern will hear from a range of voices (Siemiatycki, 2011a). The analysis suggests that ingroup candidates also drive election coverage because the tenets of newsworthiness dictate that editors and reporters will devote more attention to a story involving a candidate readers care about who is running in a riding where readers live.

Concerns arise, obviously, when no candidate from within seeks office and election coverage in general is scant. Interviews with reporters and editors about political reporting during and between elections would be helpful as a next step in understanding the news values that come into play and the barriers to expanded coverage at newspapers such as Russian Express and other publications that pay little attention to Canadian politics. A comparison of news articles published in ethnocultural newspapers and political party press releases would also be a useful way to gauge the extent to which materials are being published verbatim rather than used as the starting point for additional reporting and analysis by journalists.

Finally, the data assembled provide, among other things, a snapshot of news coverage of the 2011 Conservative campaign in ethnocultural newspapers. On their own, however, the results cannot be used to link that coverage with the outcome of the election. The fact of the matter is there is considerable debate about the extent to which ethnic voters actually 
helped the Conservatives emerge victorious from the political fray. Skeptics point to a late campaign surge of support for the NDP as the biggest contributing factor to Conservative success (Ivison, 2011) nationally and in the GTA where they finished with 32 of 47 ridings (18 more than they had going into the campaign). Canada's then-immigration minister, however, declared his party's outreach campaign a stunning success: "Polls indicate that we won at least 42 per cent of the votes of immigrants to Canada - higher than our support within the general population [and] giving us a 20 per cent lead over the Liberals among new Canadians," a jubilant Jason Kenney told the party faithful (Chase, 2011).

While immigrants accounted for more than 40 per cent of the population in 17 of the 32 GTA ridings won by the Conservatives (Statistics Canada, 2008), data on voting patterns among the foreign-born population mask important divisions. Harell's (2013) analysis of the 2004, 2006 and 2008 elections found that Conservative supporters in Ontario were older, European-origin immigrants who have been in Canada for longer. The Liberals, by comparison, continued to draw significant support from more recent arrivals who are more likely to be members of visible minority groups.

Similarly, Conservative supporters in 2011 tended to be more comfortably suburban, affluent and middle-class immigrants who have been in Canada for more than 10 years (Funke, 2011; Todd, 2011). People who arrived during the previous decade, by comparison, were more likely to back the NDP (among more recent immigrants, the party received 41 per cent of votes) rather than the Conservatives ( 28 per cent) or Liberals ( 21 per cent). The NDP actually attracted the most support among visible minorities, drawing 38 per cent of their votes, followed by the Conservatives with 31 per cent and the Liberals with 23 per cent (Funke, 2011; Todd, 2011).

What this study does show is that, while there was no overwhelming pattern of stories and photos with content skewed explicitly in favour of the Conservatives, other forms of bias were evident in Russian Express, Punjabi Post, Korea Times Daily and, to a lesser extent, in the Punjabi Daily and Ming Pao. For the most part, the party benefited from having more of its politicians featured in photographs, being the sole focus of more stories and photos than its competitors, and receiving more first mentions in news coverage. Did the CPC's strategy targeting ethnocultural news media pay off? The results of this study suggest it certainly didn't hurt.

\section{References}

Ahadi, Daniel and Catherine A. Murray. 2009. "Urban Mediascapes and Multicultural Flows: Assessing Vancouver's Communication Infrastructure." Canadian Journal of Communication 34 (4): 587-611.

Andrew, Blake, Lori Young and Stuart Soroka. 2008. "Back to the Future: Press Coverage of the 2008 Canadian Election Campaign Strikes Both Familiar and Unfamiliar Notes." Policy Options 29 (November): 79-84. 
“An Open Offer from Michael Ignatieff to Steven Harper.” 2011. Punjabi Daily, April 2, 9. Bagdikian, Benjamin. 1983. The Media Monopoly. Boston: Beacon Press.

Banerjee, Mousumi, Michelle Capozzoli, Laura McSweeney and Debajyoti Sinha. 1999. "Beyond Kappa: A Review of Interrater Agreement Measures." The Canadian Journal of Statistics 27 (1): 3-23.

Barrett, Andrew W. and Lowell W. Barrington. 2005. "Is a Picture Worth a Thousand Words? Newspaper Photographs and Voter Evaluations of Political Candidates." Harvard International Journal of Press/Politics 10 (4): 98-113.

Bascaramurty, Dakshana. 2013. "How the Punjabi Post is Joining the GTA's Mainstream Media." Globe and Mail, July 27. http://www.theglobeandmail.com/news/toronto/ how-the-punjabi-post-is-joining-the-gtas-mainstream-media/article13464039/ (August 5, 2013).

"Battle Fierce in Trinity-Spadina, Christine Innes Fighting Olivia Chow." 2011. Ming Pao, April 26, A2.

Bird, Karen. 2007. "Patterns of Substantive Representation among Visible Minority MPs: Evidence from Canada's House of Commons." European Consortium for Political Rsearch (ECPR) joint sessions of workshops (Workshop 21: Migration and representation in parliamentary democracies), Helskinki, Finland, May 7-1. http://socserv.mcmaster.ca/kbird/documents/ECPR.pdf (November 23, 2013).

"Breaking Through: Building the Conservative Brand: Conservative Ethnic Paid Media Strategy" 2011. [Leaked Conservative Party document]. Maclean's, March 3. http:// www2.macleans.ca/wp-content/uploads/2011/03/2011-03-03-breaking-through-buildingthe-conservative-brand-in-cultural-communities11.pdf (January 25, 2013).

Bricker, Darell and John Ibbitson. 2013. The Big Shift: The Seismic Change in Canadian Politics, Business and Culture and What It Means for Our Future. Toronto: HarperCollins.

Champion, Chris. 2010. The strange demise of British Canada: The Liberals and Canadian Nationalism 1964-68. Montreal: McGill-Queen's University Press.

Chase, Steven. 2011. "Tories Have Assumed Liberal Mantle, Kenney Says." Globe and Mail, June 10, A5.

Cheadle, Bruce and Stephanie Levitz. 2012a. "Government Paid for Media Monitoring of Immigration Minister's Image." The Canadian Press, November 13. http://www.theglobeandmail.com/news/national/government-paid-for-media-monitoring-of-immigrationministers-image/article5249773/ (January 25, 2013).

Cheadle, Bruce and Stephanie Levitz. 2012b. "Privy Council Office Also Spending Thousands to Keep Tabs on Ethnic Press." The Canadian Press, November 14. http:// www.thestar.com/news/canada/article/1287988-privy-council-office-spending-thousandsto-keep-tabs-on-ethnic-press (January 25, 2013).

City of Brampton. Economic Development Office. 2012. "Census Bulletin \#4: Language." Brampton: Economic Development Office. http://www.brampton.ca/en/Business/edo/ business-knowledge/Economic-Reports-Papers-Statistics/Pages/Statistics.aspx (May 8, 2014).

D'Alessio, Dave and Mike Allen. 2000. "Media Bias in Presidential Elections: A Metaanalysis." Journal of Communication 50 (4): 133-56.

Delacourt, Susan. 2013. Shopping for Votes: How Politicians Choose Us and We Choose Them. Madeira Park BC: Douglas and McIntyre.

Delli Carpini, Michael X. 2000. "In Search of the Informed Citizen: What Americans Know About Politics and Why It Matters." The Communication Review 4 (1): 129-64.

DiversiPro. 2007. Research on Settlement Programming Through the Media. Ottawa: Citizenship and Immigration Canada. http://www.settlement.org/downloads/atwork/ Research_on_Settlement_Programming_Through_the_Media.pdf (December 18, 2013). 
Diversity Institute. 2010. DiverseCity Counts 2: A Snapshot of Diverse Leadership in the GTA. Toronto: Ryerson University.

Dyble, John. 2013. Review of the Draft Multicultural Strategic Outreach Plan. http://www. theglobeandmail.com/news/british-columbia/article9791050.ece/BINARY/Review+of + the+Draft + Multicultural+Strategic + Outreach+Plan.pdf (December 4, 2013).

"Elections and the Ethnic Vote: Numbers Lottery or Political Representation?" 2011. [Video file]. Monk School of Global Affairs, October 20. http:/hosting.epresence.tv/MUNK/1/ watch/269.aspx?q=election (June 1, 2013)

Fairchild Television. 2007. Ipsos Reid 2007 Canadian Chinese Media Monitor: Greater Toronto Area. http://www.fairchildtv.com/english/ppt/ipsos_reid_2007_tor.pdf (September 29, 2013).

Fleiss, Joseph L. 1981. Statistical Methods for Rates and Proportions. 2nd ed. New York: John Wiley \& Sons.

Fleras, Augie. 2011. The Media Gaze: Representations of Diversities in Canada. Vancouver: UBC Press.

Fraser, Nancy. 1993. "Rethinking the Public Sphere: A Contribution to the Critique of Actually Existing Democracy." In The Phantom Public Sphere, ed. Bruce Robbins. London: University of Minnesota Press.

Funke, Alice. 2011. "Who Really Won the 'Ethnic' Vote in the May Election?" Pundits' Guide to Canadian Federal Elections. http:/www.punditsguide.ca/2011/09/whoreally-won-the- $\% \mathrm{E} 2 \% 80 \% 9 \mathrm{Cethnic} \% \mathrm{E} 2 \% 80 \% 9 \mathrm{D}$-vote-in-the-may-election/ (June 2, 2013).

Gaissmaier, Wolfgang and Julian N. Marewski. 2011. "Forecasting Elections with Mere Recognition from Small, Lousy Sample: A Comparison of Collective Recognition, Wisdom of Crowds, and Representative Polls." Judgement and Decision Making 6 (1): 73-88.

Gidengil, Elisabeth, Neil Nevitte, André Blais, Joanna Everitt and Patrick Fournier. 2012. Dominance and Decline: Making Sense of Recent Canadian Elections. Toronto: University of Toronto Press.

"Government of Heart—a Few Words of MP Gurbax Singh Malhi." 2011. Punjabi Daily, April 2, 16.

Habermas, Jürgen. 1989. The Structural Transformation of the Public Sphere: An Inquiry into a Category of Bourgeois Society. Cambridge MA.: MIT Press.

Hale, Matthew, Tricia Olsen and Erika Franklin Fowler. 2009. "A Matter of Language or Culture: Coverage of the 2004 U.S. Elections on Spanish- and English-Language Television. Mass Communication and Society 12 (1): 26-51.

Harell, Allison. 2013. "Revisiting the "Ethnic" Vote." In Parties, Elections and the Future of Canadian Politics, ed. Amanda Bittner and Royce Koop. Vancouver: UBC Press.

"He Made Several Trips, but Did Not Make an Appearance at Sikh Parade." 2011. Punjabi Daily, April 26, 4.

Herr Paul J. 2002. "The Impact of Campaign Appearances in the 1996 Election.” The Journal of Politics 64 (3): 904-13.

Husband, Charles. 2005. "Minority Ethnic Media as Communities of Practice: Professionalism and Identity Politics in Interaction." Journal of Ethnic and Migration Studies 31 (3): 461-79.

Hyder, Goldy. 2005. "Gaining the Political Support of Minorities in Canada." Canadian Issues (Summer): 46-48.

"I'll Get the Books in Order in 60 Days: Ignatieff." 2011. Punjabi Daily, April 18, 1.

"Immigration and Senior Citizen Issues are the First Things for Me to Work On-Manjit Grewal." 2011. Punjabi Daily, April 14, 7.

"Interview with 3 Candidates in Willowdale, the Most Korean District." 2011. Korea Times Daily, April 26, A1. 
Ivison, John. 2011. “Cookout Overlooked Layton.” National Post, August 4, A4.

Iyengar, Shanto, Helmut Norpoth and Kyu S. Hahn. 2004. "Consumer Demand for Election News: The Horserace Sells." The Journal of Politics 66 (1): 157-75.

Jenkins, Richard W. 1999. "How Much is Too Much? Media Attention and Popular Support for an Insurgent Party." Political Communication 16 (4): 429-45.

Kam, Cindy D. and Elizabeth J Zechmeister. 2013. "Name Recognition and Candidate Support." American Journal of Political Science 57 (4): 971-86.

Karim Karim H. 2002. "Public Sphere and Public Sphericules: Civic Discourse in Ethnic Media." In Civic Discourse and Cultural Politics in Canada, ed. Sherry Devereaux Ferguson and Leslie Regan Shade. Westport CT: Ablex.

Kovach, Bill and Tom Rosenstiel. 2007. The Elements of Journalism. New York: Three Rivers Press.

Kymlicka, Will. 2008. The Current State of Multiculturalism in Canada and Research Themes on Canadian Multiculturalism 2008-2010 (Catalogue no. Ci96-112/2010EPDF). Ottawa: Minister of Public Works and Government Services Canada. http:// www.cic.gc.ca/english/pdf/pub/multi-state.pdf (February 2, 2012).

Landis, J. Richard and Gary G. Koch. 1977. "The Measurement of Observer Agreement for Categorical Data." Biometrics 33 (1): 159-74.

Lindgren, April. 2011. "Interpreting the City: Portrayals of Place in a Toronto-Area Ethnic Newspaper." Aether: The Journal of Media Geography 8a: 68-88.

McKercher, Catherine, Allan Thompson and Carman Cumming. 2011. The Canadian Reporter. Toronto: Nelson.

Malo, Sebastien. 2014. "Political Consulting Firm Delivers More Newspaper Endorsements." The New York World, January 27. http://www.thenewyorkworld.com/2014/01/27/political-consulting-firm/ (April 1, 2014).

Marland, Alex. 2012. "Political Photography, Journalism, and Framing in the Digital Age: The Management of Visual Media by the Prime Minister of Canada." The International Journal of Press/Politics 17 (2): 214-33.

Meyer, Carl. 2010. "Ethnic Media Bucks Trend of Limited Cabinet Access." Embassy, September 29, 1-13.

Nadeau, Richard, Neil Nevitte, Elisabeth Gidengil and André Blais. 2008. "Who Learns What and Does It Matter?" Political Communication 25: 229-48.

Payton, Laura. 2012. "More than 30 'Very Ethnic' Target Ridings Led to Majority Government in 2011." CBC News, October 23. http://www.cbc.ca/news/politics/ ethnic-riding-targeting-key-to-conservatives-2011-victory-1.1142511 (March 10, 2014).

Putnam, Robert D. 2001. Bowling Alone: The Collapse and Revival of American Community. New York: Simon and Schuster.

Schiffer, Adam J. 2006. "Assessing Partisan Bias in Political News: The Case(s) of Local Senate Election Coverage.” Political Communication 23 (1): 23-39.

Schudson, Michael. 2011. The Sociology of News. New York: W.W. Norton.

Siemiatycki, Myer. 2011a. "The Diversity Gap: The Electoral Under-Representation of Visible Minorities." DiverseCity: The Greater Toronto Leadership Project. http:/diversecitytoronto.ca/wp-content/uploads/Final-Report.pdf (July 3, 2013).

Siemiatycki, Myer. 2011b. [The diversity gap: The electoral under-representation of visible minorities]. Unpublished raw data provided by the author.

Solutions Research Group. 2006. "Study Explores Media Use among Growing Ethnic Groups.” http://www.srgnet.com/wp-content/uploads/dc-srg-march-16-release.pdf (July 3, 2013).

Soroka, Stuart, Marc André Bodet, Lori Young and Blake Andrew. 2009. "Campaign News and Vote Intentions." Journal of Elections, Public Opinion and Parties 19 (4): 359-76.

Soroka, Stuart, Fred Cutler, Dietlind Stolle and Patrick Fournier. 2011. "Capturing Change (and Stability) in the 2011 Campaign." Policy Options (June-July): 70-77. 
Statistics Canada. 2008. Federal Electoral District (FED) Profile, 2006 Census (Catalogue no. 92-595-XWE). http://www12.statcan.ca/census-recensement/2006/dp-pd/prof/92595/p2c.cfm?TPL=INDX\&LANG=E (July 3, 2013).

Statistics Canada. 2012. Toronto, Ontario (Code 535) and Ontario (Code 35) (table). Census Profile. 2011 Census (Catalogue no. 98-316-XWE). http://www12.statcan.gc.ca/censusrecensement/2011/dp-pd/prof/index.cfm?Lang=E (March 27, 2013).

Taber, Jane. 2011. "Journalist Angelo Persichilli Replaces Soudas at PMO." Globe and Mail, September 1, A4.

Todd, Doug. 2011. "Poll: How Religion and Ethnicity Shaped Canada's 2011 Election." Vancouver Sun, May 9. http://blogs.vancouversun.com/2011/05/09/poll-how-religionand-ethnicity-shaped-canadas-2011-election/ (June 3, 2013).

Wells, Paul. 2013a. "Harper's Brandon Letter, the Demon Weed, and Justin Trudeau." Maclean's, November 21. http://www2.macleans.ca/2013/11/21/harpers-brandonletter-and-the-demon-weed/ (November 28, 2013)

Wells, Paul. 2013b. The Longer I'm Prime Minister: Stephen Harper and Canada, 2006. Toronto: Random House.

"Worried about Scaring Away Investment, Business Appeals to Not Have Corporate Tax Cuts Taken Away.” 2011. Ming Pao, March 5, A11.

$\mathrm{Yu}$, Sherry S. and Daniel Ahadi. 2010. "Promoting Civic Engagement through Ethnic Media." PLATFORM: Journal of Media and Communication 2 (2): 54-71.

Zelizer, Barbie. 2004. Taking Journalism Seriously. Thousands Oak CA: Sage.

Zhou, Min and Guoxuan Cai. 2002. "Chinese Language Media in the United States: Immigration and Assimilation in American Life.” Qualitative Sociology 25 (3): 419-41. 